\title{
Using Video Games for Teaching History. Experiences and Challenges
}

\author{
By Laura Radetich ${ }^{*}$ \\ Eduardo Jakubowicz ${ }^{\dagger}$
}

The starting point of this project was the research seminar "Planning lessons with video games," issued in 2013 as part of the offer grade for preparing future teachers of History at Faculty of Philosophy and Literature in the University of Buenos Aires. This seminar aimed to open a debate on the use of video games to teach history, so experiences were developed as a method by applying action research institutions in public and private management. The focus of the program was the importance of the game in learning environments and focus on action research in the context of theories of learning, working with this investigative modality as a learning strategy for training of trainers and teachers of history. We will describe the basic theoretical elements of this experience.

\section{Introduction}

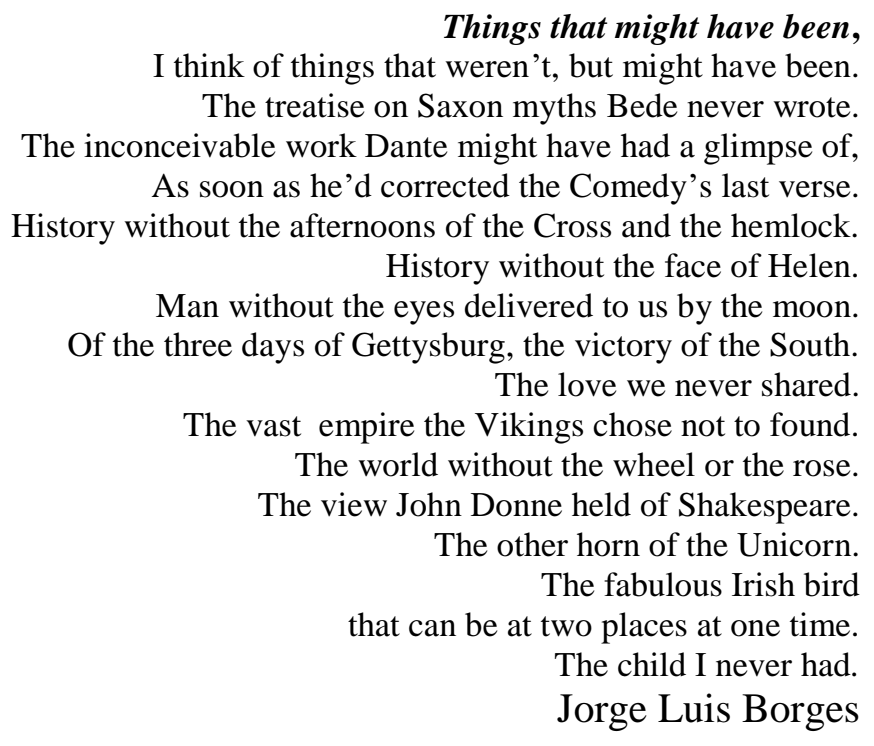

The research Seminar, "Planning lessons with video games," was given as an undergraduate seminar for History teacher-training at the Filosofía y Letras School of the University of Buenos Aires. Its aim was to open a debate on the

${ }^{*}$ Professor, Didactics of History, University of Buenos Aires, Argentina.

${ }^{\dagger}$ Professor, Institute of National University of Art, Argentina. 
use of video games in History teaching. For this purpose, classroom experiences were conducted applying action-research methodology in public and private institutions of the metropolitan area of Buenos Aires (AMBA).

The importance of video games in learning environments is related to the dynamics of the interaction between the game and the symbolic universe created by the learner. This interaction is supported by the immersion process, which facilitates a sense of belonging to those environments and the development of a particular narrative. According to $\operatorname{Bruner}^{1}(2013,141)$, the language of History is part of what "is", thus being indicative, whereas the language of a videogame could be considered subjunctive or the language of what "might be" (counterfactual History). This strategy helps learners question the narrative of historiography from argumentation, and it implies an exercise of reconstruction and reorganization of the information, a process which Edgar Morin would call complex thought, one which integrates, orders, clarifies, distinguishes and gives accuracy to knowledge.

Other authors state: Why should one read about Ancient Rome if they can construct it ${ }^{2}$. Studies indicate that youngsters today play during more hours than those they dedicate to reading or even television. However, educators do not seem to understand the circumstances in which simulation sparks teenage curiosity and produces an interaction with alternative worlds that other media do not succeed in attaining.

"Civilization III can offer a story of advantageous geographical conditions that provides access to global trade networks, resources, technologies, and limited op- portunities for population expansion. In the words of one stu- dent, the game shows "how geography and gold (i.e., materialist goods) determine how history plays out". Thus Civilization III enlisted students' identities as gamers and created a space where they could bring their own experiences to the study of world history"3.

Kurt Squire agrees that video games provide a logic which allow bringing forth a change in education paradigms, until now based on "learning about" to ones based on "learning to do" and "learning to be", redirecting the focus of teaching.

In turn, Gee wonders why schools and other teaching institutions should use the norms contained in good video games. The answer is that video games place emphasis on the resolution of problems. They offer a good synthesis of practice and orientation. They use language and display complex concepts when necessary, i.e. when these can be used and understood better. A lot of time is needed to carry out tasks, but the players are motivated to endure it since the games pose a sequence of challenges with growing degree of difficulty, in a way that they are constantly making full use of their abilities,

\footnotetext{
${ }^{1}$ Jerome Bruner, La fábrica de historias. Derecho, literatura, vida, trans. Luciano Padilla Lopez (Buenos Aires, 2003), 14.

${ }^{2}$ S. Moulder, "Fun with a purpose" (presentation, Serious Games Summit, San Jose, CA, March, 2004). This comment was made by an elementary student via video at the 2004 Serious Games Conference, San Jose, CA.

${ }^{3}$ Kurt Squire, Video Games and Learning: Teaching and Participatory Culture in the Digital Age (New York: Teachers College Press, 2006), 312.
} 
producing what psychologists and designers call the "state of flow", one of great excitement and concentration ${ }^{1}$. This state is what we know as immersive, or learning through immersion.

This criterion, based on problem resolution and decision-making, is the one used by companies. Video games, according to $\mathrm{Gee}^{2}$, propose a kind of teaching founded on simulation and tend to train young people to comply with these aims

From the theoretical aspect in connection with practical experience as mentors in Educational research, criteria of pedagogical action will be suggested for the training of Education professionals with regulating abilities to plan, orientate and assess their own cognitive processes related to the content to be taught and those linked to their teaching practice. In this fashion, the training of trainers should direct youngsters to new narratives which support critical thought and analysis, in order to guarantee a necessary change in high school education.

In our project, the trials were carried out in their set time limits and the main focus was put on the teenagers' attitudes toward a strategy video game. As a result, other phenomena were detected, as emerging from the community of practice which the video game has created.

Few studies have been conducted on the surroundings or the influence of social structure on formal education ${ }^{3}$. Nonetheless, this does contradict the existence of military organizations and political parties from the extreme right that invest in these technologies, which have an impact on specific social groups - e.g. young high school and college students, unemployed youth, especially male, etc. - . Obviously, the video games are ideological, since the "wisdom" transmitted from behind the joystick is implicit, or else a collective learning of players on line.

Thus, future educators should be critically reflective when engaging in History-teaching with video games, for which the role of instruction changes from content transmission to the design of experiences. Many questions still remain without answer, such as the way games create and mobilize hybrid identities in young players, and how these identities embody through different contexts. However, the conflict between the logic of games and the logic of teaching poses even more puzzling questions: How will students react to school-designed experience? What will happen to their potential to claim identities for themselves? Will they be able to do it with freedom within the school framework?

James Paul Gee argues that video games are an ideal laboratory for the study of the principles of learning, since, as they increase in complexity, game designers integrate and develop frameworks that help players learn from them.

\footnotetext{
${ }^{1}$ James P. Gee-David W. Schaffer "Looking where the light is bad. Videogame and the future of assessment". Phi Delta Kappa International EDge 6, no. 1, (2010): 3-19, accessed January 3 2015, http://edgaps.org/gaps/wp-content/uploads/EDge-Light.pdf.

${ }^{2}$ James Paul Gee, What video games have to teach us about learning and literacy? (New York: Palgrave Macmillan, 2003).

${ }^{3}$ See Gee, 2003; McFarlane,Gavilán and Heald , 2002 ; Squire, 2004.
} 
The examination of these features can provide ideas about the design of learning environments - specifically educational software. Virtual worlds in particular could help us understand how to build up distributed communities of practice, or affinity groups, which extend through the real world connected by high tech communications, such as mobile phones and the Internet.

\section{Records of the Intervention in the Classroom}

After the formative assessment, we went on to hear all existing points of view on the problems and objectives. We attempted to deliver a diagnosis and collect possible proposals arising from our own praxis. We also developed assessment tools (survey and semi-structured interviews) which enabled a descriptive interpretation of the effect produced by the proposed change.

The strategy video games about History are the ones that offer the best narrative we can find in the market. History as a narrative is flexible enough to generate "histories", or narratives that can be endogenous or exogenous to the chronology. The endogenous games - which are the most advisable - are those in which the context and the game are inextricably linked, as is the case of Universalis, Civilization III or Forge of Empires II. In these games, we find chronologies and manuals with great historical accuracy, which allows their adjustment to the school curriculum.

New technologies entail advances in practice. However, one of the main barriers to this kind of research is the difficulty to suit computer rooms to learning communities. While the traditional classroom may be effective for an ordinary History class, in which the information is transmitted, this does not mean students will learn to view the past with curiosity. In this case, motivation is a useful medium for proposing strategies of reading comprehension, giving concepts their historical meaning and establishing connections between present and past.

On the other hand, if a videogame within a learning community is used as a means for motivation, it is clearly perceivable that the difference between knowledge and knowing is overcome only by joining and acting in a community of practice, which in turn serves as assessment of the actions during the game.

Therefore, it is clear that video games maintain a close relationship with learning and this fact has not been ignored but, quite contrarily, there have been a number of teachers and researchers dedicated to study that phenomenon. In the last thirty years, among the advocates of what has been called Digital Game-Based Learning (DGBL), three distinct approaches have emerged to address the use of video games in formal instruction ${ }^{1}$, attempting to reconcile pedagogy with the power of a video game to entertain. In the first approach, students play the role of game designers and learn the contents while creating the game. The second approach is to use games designed for teaching, the so-

${ }^{1}$ Richard Van Eck, R.. "Digital Game-Based Learning: It's not just the Digital Natives who are Restless...." Invited cover story for Educause Review 41, no. 2 (March/April, 2006): 16-30. 
called "serious games", where learning and playing are integrated. Finally, the third approach aims to integrate commercial video games and classroom teaching.

As this experience was done specifically for teaching History, historiographical problems in current video games and the possibilities of eventual change will be presented. It is known that video games are strongly biased on the ideology of the world powers, such as the United States and the European Union. On the other hand, many historians argue that they generate a non-existent History, because the game is narrated by its player - in this case the high school student.

\section{Seminar on Video Games Applied to the Teaching of History}

The seminar aimed to propose this method of research implicitly. The students of History had to adjust their research methods for planning and implementation assuming new technologies as a problem.

This new scenario demands teachers to acquire skills that enable them to adapt to the needs of today's society, moving from the role of knowledge transmitter to one of facilitator, guide and promoter of the appropriate teaching practices.

However, it must be mentioned that one of the areas in which the use of ICT and technological adjustments has had greater relevance is education ${ }^{1}$. At first, we pondered the extent to which content is assimilated and how it can be objectivized by students from video games, for which the proposal was to observe youngsters' attitudes in front of the screen. The degree of concentration shown by them during the video games in all experiences can be described as an immersive type of learning. Another consistent phenomenon was the changes in the way teenagers interact with the screen and the kind of skills developed during the game. Knowing the logic of a game allowed some of them to handle it with ease and accomplish their goals rapidly, whereas another 50\% failed to integrate or abandoned the game achieving no results.

Furthermore, the studies showed that out of 22 young women who used video games, only 10 (ten) attained the appropriate degree of concentration necessary to intervene effectively in the development of the game's narrative. The others dropped out or just let male students take over, from which another working hypothesis: women are not as attracted to strategy games as men.

\footnotetext{
${ }^{1}$ See Pilar Arnáiz, "Effective and inclusive schools: How to promote their development" Educatio Siglo XXI 30, no.1 (2012): 25-44; D. J. Luque, G. Rodríguez, and J. F. Romero, “Accesibilidad y Universidad. Un estudio descriptivo." Intervención Psicosocial, 14, (2005): 209-222.
} 


\section{Two Arguments}

The advantage of immersive environments, such as virtual worlds, is that they can produce a strong identification of the juveniles with their characters, due to the immersion and the possibilities video games provide through the use of so-called avatars.

According to Inés Dussel ${ }^{1}$ there are two arguments for the development of strategies with the use of screens.

First of all, there is one which makes reference to the importance of image in contemporary culture. Secondly, there is another argument, not inconsistent with the former, that images are motivational and can attract the interest of youngsters - an interest which is far from guaranteed to get in the classrooms of today.

The implementation of screens and particularly video games in classrooms has, as assets, empathy and proximity, narrative independence and the construction of sequences that serve as simulations of the historical discourse. The didactic argument proves effective when motivation leads a youngster to propose alternative analysis and create narratives that challenge and criticize the History taught at schools.

The narrative of video games built by students is counterfactual, because it is the history that "might have been". By this means, students become subjects and narrators of their own voyage and select their actions carried out by an avatar. In this sense, it can be said that they prefer a game to a film, because the game is an interactive display and moves the focus of the narrative to the player. The leading star is the player himself, i.e. the student.

In the studies developed by Dr. Ana Lilliestam ${ }^{2}$ in Sweden, Eric Lund's theory is applied to spot the meaning structures shown by young students learning from counter-factuality. Eric Lund states that there are three dimensions of meaning. The dimension of extension, the dimension of intention, the dimension of value, which refers to the affective meaning, encompassing ideas such as attitude, motivation, desire, reinforcement and interests, all nominated by different schools of psychology. The affective component expresses the value of meanings.

It is psychology which has shown greater interest in counterfactual thinking since the proneness of human beings to explore and, likewise, to

\footnotetext{
${ }^{1}$ Research Professor, Department of Educational Research -IPN CINVESTAV, Mexico . She holds a PhD in Education (Ph.D. ) degree from the University of Wisconsin- Madison. Its formation is based on Educational Sciences, University of Buenos Aires, and Account Also with a master's degree in Social Sciences FLACSO / Argentina. She was a fellow of Spencer ( USA), DAAD ( Germany), CNPq (Brazil ), the University of Buenos Aires (Argentina ) and the Georg Eckert Foundation - Institut in Germany (Germany ). See Dussel I. - Quevedo (2010) Aprender y enseñar en la cultura digital, (presentation, VII Foro Latinoamericano de Educación / Experiencias y aplicaciones en el aula. Aprender y enseñar con nuevas tecnologías. Documento Básico / Fundación Santillana, accesed January 3 2015. Available at: oei.es/noticias/spip.php?article8862.

${ }^{2}$ A.-L. Lilliestam, "Kontrafaktisk historia som pedagogisk metod" (presentation, Conference at Didactic Congress in Middelfart, Denmark, CA, May13-15, 2009) Accesed January 3, 2014, http://www.historieweb.dk/cms/upload/news_85_7953.doc> University of Gottenburg
} 
experience the influence of the alternatives they themselves build, is directly related to emotions and one's social and self-perception ${ }^{1}$. Thus, in the early 1970 's, cognitive psychology became interested in counterfactual thought to explain the basic processes of learning and memory. During the 1980s, social psychology linked it with feelings, perceptions, motivations and goals of the individual in the broader framework of social interaction among human beings. In the 90s behavior theorists focused their attention on the function it may serve, as it allows to learn how to deal with future situations based on the analysis of errors in the past and to recognize the positive aspects of the present comparing reality with less satisfactory alternatives. And finally, the turn of the century has seen a revision of this functionalist approach and the emergence of new theoretical outlooks concerning the link to the notion of causality and the processes of mental representation, simultaneously to the consolidation of the use of counterfactual thinking as a method of investigation ${ }^{2}$.

Paradoxically, although counter-factual history is not part of true history, it does not totally escape it, allowing to free its fictional component from the restrictions imposed by historical plausibility and, on the other hand, provide its historical component with the richness of a realistic context ${ }^{3}$.

The harshest appraisal of historical counter-factuality was expressed in 1978 by Edward P. Thompson to include what he called "counter-factual fiction" in the enumeration of his particular historiographical demons, applying a very unflattering term drawn from the correspondence between Marx and Engels, Geschichtenscheissenschlopff: "unhistorical shit" 26.

History That Never Happened. A Treatise on the Question, What Would Have Happened If...? written by Alexander Demandt, alien to the Anglo-Saxon academic world and thus unmentioned in the historiographical analysis performed by some of its most prominent representatives even after its translation (thus, e.g., Ferguson 1998), intends to show that our view of history is incomplete if it does not address the unrealized possibilities, and that "the History that never was... has an educational value which helps to better understand the true History...: its starts off from and returns to the real History. To fulfill his aim, Demandt begins reviewing the criticism received by counterfactual reflection and explaining that it is necessary to round off our knowledge, understand the different situations and their potential towards the future, judge causes, make value judgments and assess possibilities. Then he goes on to justify the study of the contingent versus the necessary, and collects a series of events from which history could have been different. After that, he recognizes the difficulties that constructing a history that never happened faces.

\footnotetext{
${ }^{1}$ N.J. Roese, "Counterfactual thinking”, Psychological Bulletin 121, no. 1 (American Psychological Association 1997):133-148.

${ }^{2}$ This trend on contrafactual thinking is not restricted to the field of Psychology; it has been implemented in Science History (Fuller, 2008), the educational system (McCulloch 2003), management (Maielli \& Booth 2008), marketing (Roese 2000), consumption (Cooke \& Meyvis \& Schwartz 2001), language (Coleman 2010), literary discourse (Riddle Harding 2007), biography (Rodden \& Rossi 2010) or geography (Gilbert \& Lambert 2010).

${ }^{3}$ Edgar V Jr ,McKnight. The alternate history. A development of a literary genre, (Ph.D diss. University of North Carolina, 1994).
} 
And finally, he notes down some directions in which counter-factuality may be useful. Of similar German procedence is the first $\mathrm{PhD}$ thesis whose object of study was alternative history, defended in 1987 by Jörg Helbig at the Free University of Berlin and entitled Der parahistorische Roman. Ein literarhistorischer und gattungstypologischer Beitrag zur Allotopieforschung. This focuses on both, the actual historical approach and the fictional narrative.

Wayne Dumas, who in January 1969 published a brief article in Social Education magazine called "Speculative Reconstruction of History: A New Perspective on an Old Idea", defended the use of alternative history in classrooms whereby he considered speculative reconstruction as a teaching technique that "provokes students at every point of the sequence of challenges faced by the historian and the user of historical knowledge" ${ }^{1}$. Already in the 70 s, several authors approached the topic on proposing new teaching tools for history lessons.

Cooper considered that the methodology of alternative history encourages students to suggest new situations for the past, yet requires, as well, to accept the responsibility of developing logical speculations on the nature and meaning of the alternative past one has built. Avoiding casual judgements, arbitrary guesswork and unfounded or anachronistic remarks are undelayable tasks of a teacher who directs students' exploration of modified historical settings, but also of the students themselves, now turned into "speculative historians".

Although the format could seem rather odd, the methodology is solid, almost traditional, in the sense that each student must quote the potential sources of information on their "new" latest historical event, indicate the types of political, economic, social, intellectual and religious consequences that would emerge from the proposed historically modified scenario; and, finally, assess critically "what was" and "what might have been" in view of the implications of each context for the eventual development of mankind. And although it is not easy, investigating the results of the actual events in order to judge the consequences of an altered past should encourage the student to the point of generating a new creative atmosphere in history classrooms.

Alternative history in classrooms move students from their traditional role as passive observers and turns them, on the one hand, into would-be historians, and on the other, into subjects forced to make decisions and solve problems, i.e as participants of History: this becomes an interactive way of understanding what happened and what could have happened, and undermines the myth of historical inevitability, as it shows how any particular event is a result of multiple causes, currents and influences ${ }^{2}$.

"Things happened the way they did, but could have happened otherwise" ${ }^{3}$. Hernández Cardona and Cuenca hence began on a path that they have

\footnotetext{
${ }^{1}$ Wayne Dumas, "Speculative Reconstruction of History: A New Perspective on an Old Idea", Social Education Magazine no .55, vol. 34, Issue 8, (Education Digest, April, 1969):54.

${ }^{2}$ Stephen, Kneeshaw, "«What If...»: Alternative History, or Teaching What Might Have Been”, History and Social Science Teacher 18. no. 1, (1982): 3-7.

${ }^{3}$ F. X., Hernàndez Cardona, "Los juegos de simulación y la didáctica de la historia", Íber 30, (2001): 23-36.
} 
continued in further works up to the present ${ }^{1}$ in advocation of the use of classroom games and simulations through which students can develop counterfactual approaches. As a result, they can build alternative histories to prove that there may be different solutions to historical problems from the ones that in their day were taken and therefore, interact with history and more easily understand the facts ${ }^{2}$. And "that is precisely what is interesting about simulation in history: it shows that things might happen in one way or another depending on how people decide. There are no small decisions, a minimum action is important, and there is no 'predestination'" ${ }^{3}$.

\section{ME, the Avatar}

The subject of action is not, say, Napoleon or Julius Caesar, but the representation of oneself, and once the characteristics are assumed, the power to forge one's own destiny is acquired, walking virtually through this cosmos deciding actions and interactions. The videogame moves a teenager's role from observer to "player" and compels them to act explicitly in the fictional environment. In other words, the student becomes an "actor" and the video game, a didactic means through which they can make mistakes, re-run the action and release their creativity, allowing them to self-assess their actions and reflect on the imaginary construct of this past in which they intervened.

\section{Video Games and the Ideology of Domination}

A number of educators argue that a video game is not a suitable means for formal learning. Notwithstanding, American corporations and the US armed forces have invested billions of dollars in tweaking multiplayer games online, which have the ability to generate sympathy among players since trainees are guided by experts and thus improve the team's performance, turning it into a learning community.

This strategy of communication done by U.S. military and neo-Nazi groups is aimed at teenagers and juveniles who are immersed in the culture of the game. Following historian - specialized in video games - Dr. Kurt Squire's line of thought, it could be said that video games are a way of imposing ideology implicitly. For which schools should asume the role of guidance in the use of games, both for analysis and to integrate them critically in the social life of the students.

\footnotetext{
${ }^{1}$ See Cuenca 2001-2006; and Hernandez Cardona 2001; 2007: 140 and 173; 2010; Pelegrin (2010), and which other authors have joined Gómez García 2006; have joined Pérez, Oliva , Ciaurriz \& Guerrero-Sole (2008).

${ }^{2}$ Cuenca and Martín "La resolución de problemas en la enseñanza de las ciencias sociales a través de videojuegos" Iber:Didáctica de las Ciencias Sociales, Geografia e Historia, (January-March 2010):36-37.

${ }^{3}$ Hernandez Cardona, F. X., op. cit.
} 
From film video games take its particular form of narrative, with the substantial difference that the viewer of a film is passive, a voyeur, while the game is interactive and takes the player to the space and time of the constructed narrative. In these environments, the narrator and character's knowledge derives from the break-up of the dramatic scene and the perception of the narrative is dispersed under the dominance of a new perspective"1

The authorship of a history in which the plot is developed by students does not make them historians, but it does allow them to exercise different criteria for decision-making. On building up the plot, they are forced to think about the causes of their choices, the reason for their actions. This type of narrative, according to Murray, is kaleidoscopic, because the environment offers the opportunity to view the simultaneous actions. Hence, decisions are made from different perspectives and complexity.

Consequently, the use of videogames in the history classroom implies more work for teachers, who must propose strategies tested and revised for teaching. This involves research to improve planning and give up the old evaluation paradigms, exploring other formats that ensure a proper assessment of creative learning and students' capacity of deconstructing discourse, as the game addresses other levels of inference, different from the ones we know.

\section{Temporality, Causality, Multicausality, Multiperspectivity, etc}

In strategy games such as Age of Empire, great socio-economic changes tend to be gradual, and often several intermediate steps are needed, which delay change even longer. All these games force the player to understand historical evolvement from multiperspective causes which encompass social, economic, political and cultural aspects. The strategies required for succeeding in the game call for cognitive levels and high-degree thinking which are not normally developed in the traditional history lesson.

The most tangible signs of the cognitive fields stimulated by historical strategy games are the timelines included in most of them. These timelines come in different formats and with content according to the needs of each game and become more and more complex with the advance in information technology, providing more information and enabling a higher degree of interactivity with the player, i.e. the player can manipulate and take part in them. These timelines contribute to the development of players' historical thought and their perception of chronology, related to the ideas of succession, simultaneity and causation (cause/effect). The player produces a sequence of historical events with each decision, understanding that this event has a series of immediate and remote causes, triggering equally close or distant consequences.

\footnotetext{
${ }^{1}$ Esnaola and Levis, "La narrativa en los videojuegos: un espacio cultural de aprendizaje socioemocional", Revista Electronica Teoria de la Educacion. Educacion y cultura en la Sociedad de la información 9, no. 3, (Salamanca, Ed. USalamanca, 2008):48-68.
} 
In this line, strategy games in the AOE style, such as Empire Earth and others provide an interactive timeline where progress in the game results in the development of technologies associated with the chance of obtaining buildings, military units, resources and manufactured goods, which allow greater economic, demographic and social growth.

Each technology is given a certain degree of power and extension, obtained automatically. In the case of Universalis, history unfolds in a "true-tolife" way along with the passage of time, depending on the progress in achieving the targets that each step of the timeline requires. Unlocking a particular technology allows to begin working on the next in a cause/effect relation which is evident because it is sought consciously by the player.

The game Sid Meier's Civilization had already contributed with great historical accuracy in its time setting, thus making a very useful teaching tool for the player. However, those chronological lines had the handicap of being only orientate and not essential to the development of the game (something common in others, like in Age of Empires), allowing a player to ignore them and get on with the game straight away (although hindering their performance). Therefore, as we intend to show, Forge of Empires has developed a keen tool, yet with content that in our opinion could be improved by simply applying greater historical accuracy in the concepts chosen for the chronological succession.

\section{New Research Lines in Historiography}

The use of video games proposes presents an epistemological turn of various dimensions in historiographical analysis. Mainly, the concept of truth is put into question, since the games divert from the basic discipline and construct a new rhetoric founded on a plausible history, a rewrite of what might have happened b6ased on the knowledge of the existing variables presented by history. Thus, the Aristotelian truth is checked; current epistemology offers the more relative idea of plausibility.

Koselleck ${ }^{1}$ states an alternation in which he distinguishes between tell (erzählen) and describe (beschreiben); the narrative's structure is related to description whereas the event is associated to telling. Games, however, offer the possibility of changing the past, based on the awareness of true events yet considering a different resolution of its problems with the existing variables.

The game itself does not make use of historiographic fundamentals on developing a narrative but creates an alternative unfolding "as if [it had] really happened" ${ }^{2}$ which forms part of its meaning, for which it is difficult to deny what could be true. This relates to the Postmodernist idea of the relativity of

\footnotetext{
${ }^{1}$ Reinhart Kosselleck, "Futuro, pasado. Para una semiotica de los tiempos históricos (Le futur passé, contribution à la sémantique des temps historiques; Die Vergangene Zukunft. Zur Semantik geshichtlincher Zeiten):291-295 in Ricoeur, Paul La memoria, la historia, el olvido (Argentina, Fondo de Cultura Económica, 2004):345.

${ }^{2}$ Paul Ricoeur, La memoria, la historia, el olvido (Argentina: Fondo de Cultura Económica, 2004), 344.
} 
truth, hitherto overestimated, and paving the way for new perspectives and interpretations of the past ${ }^{1}$.

Hence, it is possible to ponder a lateral turn in the epistemological approach of History, in which a quasi past with quasi characters is created, deriving from the paradigm of counterfactual or alternative history. This proposal enables the formulation of new questions on history and the generation of new responses as a testing laboratory where "correct" answers become merely "plausible". Although it may be linked with the plausibility that Aristotle attributed to epic or tragic fables, it can also be used as a narrative from which new hypothesis can stem.

\section{References}

Arnáiz, Pilar. "Effective and inclusive schools: How to promote their development", Educatio Siglo XXI 30, no.1 (2012).

Bruner, Jerome. "La fábrica de historias. Derecho, literatura, vida", translated by Luciano Padilla Lopez. Buenos Aires, Fondo de Cultura Económica, 2003.

Coleman, M. C. "«You Might All Be Speaking Swedish Today»: language change in 19th century Finland and Ireland", Scandinavian Journal of History 35. no.1 (2010): 44-64.

Cooke, A. D. J., T. Meyvis and A. Schwartz, "Avoiding Future Regret in PurchaseTiming Decisions", Journal of Consumer Research 27, (2001): 447-459.

Cuenca and Martín "La resolución de problemas en la enseñanza de las ciencias sociales a través de videojuegos" Iber:Didáctica de las Ciencias Sociales, Geografia e Historia ( January- March 2010):32-42.

Demandt, Alexander. History That Never Happened. A Treatise on the Question, What Would Have Happened If...? North Carolina: Mc. Farland \& associated, 1993.

Dumas, Wayne. "Speculative Reconstruction of History: A New Perspective on an Old Idea”. Social Education Magazine no. 55, vol.34 Iss. 8 (Education Digest, April 1969):54.

Dussel Ines - Quevedo Aprender y enseñar en la cultura digital, VII Foro Latinoamericano de Educación / Experiencias y aplicaciones en el aula. Aprender y enseñar con nuevas tecnologías. Documento Básico / Fundación Santillana (2010) available at: oei.es/noticias/spip.php?article8862.

Esnaola and Levis. "La narrativa en los videojuegos: un espacio cultural de aprendizaje socioemocional", Revista Electronica Teoria de la Educacion. Educacion y cultura en la Sociedad de la información, (2008), Available at: usal. es/teoriaeducacion.

Fuller, S., "The Normative Turn: Counterfactuals and a Philosophical Historiography of Science", Isis 99.3, (2008): 576-584.

Ferguson, Niall "Virtual History: Towards a «chaotic» theory of the past", Virtual History: Alternatives and Counter-Factuals, Madrid: Taurus, 1998).

Gómez García, S., "Playing with the past: the role of digital games in how we understand History”, in A. Méndez-Vilas, A. Solano, J. Mesa, J. A. Mesa (eds.),

${ }^{1}$ Hayden White, Ficción histórica, historia ficcional y realidad histórica, (Buenos Aires: Prometeo, 2010), 169-182 
Current development in technology-assisted education, vol.3. Badajoz: Formatex, 2006.

Gee, James Paul. What video games have to teach us about learning and literacy? New York, Palgrave Macmillan, 2003.

Gee, James Paul. "Learning by design: good video games as learning machines", $E$ Learning 2, no. 1 (2005): 5-16.

Gee, James Paul. Good video games and good learning: Collected essays on video games, learning and literacy. New York: Peter Lang, 2007.

Helbig, Jörg. Der parahistorische Roman. Ein literarhistorischer und gattungstypologischer Beitrag zur Allotopieforschung. New York: Peter Lang,1988.

Hernàndez Cardona, F. X., "Los juegos de simulación y la didáctica de la historia", Íber 30, (2001):23-36.

Reinhart Kosselleck. "Futuro, pasado. Para una semiotica de los tiempos históricos (Le futur passé, contribution à la sémantique des temps historiques; Die Vergangene Zukunft. Zur Semantik geshichtlincher Zeiten):291-295 in Ricoeur, Paul La memoria, la historia, el olvid,. (Argentina, Fondo de Cultura Económica, 2004):345.

Kneeshaw, S. "«What If...»: Alternative History, or Teaching What Might Have Been", History and Social Science Teacher 18.1, 3-7 (1982).

Lilliestam, A.-L. Kontrafaktisk historia som pedagogisk metod. Conferencia pronunciada en las jornadas sobre didáctica celebradas en Middelfart (Dinamarca, 13-15 mayo de 2009: http://www.historieweb.dk/cms/upload/news_85_7953. doc> (consulted 15 octobre 2013). Universidad de Gotenburgo.

Luque, D. J., G. Rodríguez and J. F. Romero. "Accesibilidad y Universidad. Un estudio descriptivo". Intervención Psicosocial, 14, (2005):209-222.

Lund, Erik. Historiedidaktikk. En håndbok for studenter og laerere. 2 utgave. Oslo: Uniersitetsforlaget in Lilliestam, Ana Kontrafaktisk historia som pedagogisk metod. consulted 15 octobre 2013). University of Gottenburg.

Maielli, G. and Ch. Booth. "Counterfactual history, Management and Organizations: Reflections and New Directions", Management and Organizational History 3.1, (2008):49-61.

McCulloch, G. "Virtual history and the history of education", History of Education 32, no. 2, (2003): 145-156.

McKnight, Edgar V Jr. "The alternate history. A development of a literary genre", $\mathrm{PhD}$ diss., University of North Carolina, 1994.

Morin, Edgar, Introducción al Pensamiento Complejo. 2001, 4a reimpresión, Barcelona: Gedisa, 1990.

Moulder, S., "Fun with a purpose." Presentation at the Serious Games Summit, San Jose, CA, March, 2004.

Murray, Janet. H. Hamlet en la holocubierta - el futuro de la narrativa en el ciberespacio. Barcelona: Paidos, 1999.

Pelegrín, J. "La historia alternativa como herramienta didáctica: una revisión historiográfica", Proyecto CLIO, 36. (2010) accesed January 2015. Available at: http://clio.rediris.es

Pievi, N - Bravin, C. Methodological guidance document for educational research, Buenos Aires: National Ministry of Education, 2009.

Riddle Harding, J., "Evaluative stance and counterfactuals in language and literature", Language and Literature 16, no.3, (2007):263-280.

Rodden, J. and J. P. Rossi. "If he had lived, or a counterfactual life of George Orwell", Prose Studies, 32. no.1, (2010): 1-11. 
Roese, N.J. "Counterfactual thinking” in Psychological Bulletin, 121, (1997):133-148.

Roese, N, J. and J.M. Olson, What might have been: the social psychology of counterfactual thinking (2000):133-167.

Squire, K. D. "Educating the fighter: buttonmashing, seeing, being", On the Horizon 13 , no.2 (2005).

Squire, K. D., and S. A. Barab. "Replaying history". In Y. Kafai, W. Sandoval, N. Enyedy, A. Dixon and F. Herrera (Eds.), (Proceedings of the 2004 International Conference of the Learning Sciences, 2004):505-512

Squire, Kurt Video Games and Learning: Teaching and Participatory Culture in the Digital Age (New York, NY: Teachers College Pres, 2011):312.

Squire, K. D., and C. A. Steinkuehler. "The genesis of "Cyber-Culture": The case of Star Wars Galaxies". In D. Gibbs \& L. Krause (Eds.), Cyberlines: Languages and cultures of the Internet (2nd ed.) (Albert Park, Australia: James Nicholas Publishers, 2013).

Squire, Kurt. "From Content to Context: Videogames as Designed Experience". Educational Researcher, 35. no.8, 19-29. Sage Publications. Retrieved from http://edr.sagepub.com/cgi/doi/10.3102/0013189X035008019

Thompson, E.P. The Poverty of Theory and Other Essays, London: Merlin Press, 1978, in J. Pelegrín "La historia alternativa como herramienta didáctica: una revisión historiográfica", Proyecto CLIO, 36. (2010).

Van Eck, Richard. "Digital game-based learning: It's not just the digital natives who are restless... Invited cover story for Educause Review 41, no.2, (March/April, 2006).

White, Hayden, Ficción histórica, historia ficcional y realidad historica. Buenos Aires: Prometeo, 2010. 